Jurnal Keperawatan Silampari

Volume 4, Nomor 2, Juni 2021

e-ISSN: 2581-1975

p-ISSN: 2597-7482

DOI: https://doi.org/10.31539/jks.v4i2.1931

\title{
PERSEPSI PENYAKIT DAN PERAWATAN DIRI DENGAN KUALITAS HIDUP DIABETES MELLITUS TYPE 2
}

\author{
Fitriyanti Nurdin \\ Universitas Muhammadiyah Jakarta \\ fitriyantinurdin36@gmail.com
}

\begin{abstract}
ABSTRAK
Penelitian ini bertujuan untuk mengetahui hubungan antara persepsi nyeri dan perawatan diri dengan kualitas hidup penderita diabetes tipe 2. Metode penelitian ini adalah penelitian kuantitatif dengan pendekatan studi potong lintang. Hasil penelitian menunjukkan mayoritas responden berjenis kelamin perempuan, usia responden mayoritas 54,7 tahun, pendidikan responden mayoritas SMA-PT, pengobatan DM mayoritas menggunakan pil / obat oral, mayoritas komplikasi DM adalah neuropati, mayoritas sudah lama menderita DM yaitu rata-rata 7,85 tahun, ada hubungan yang signifikan antara persepsi nyeri dengan perawatan diri, ada hubungan yang signifikan antara persepsi nyeri dengan kualitas hidup DM, tidak ada hubungan yang signifikan. Simpulan, tidak terdapat hubungan yang signifikan antara persepsi sakit dengan kualitas hidup DM tipe 2. Tidak terdapat hubungan yang signifikan antara perawatan diri dengan kualitas hidup DM tipe 2.
\end{abstract}

Kata Kunci: Diabetes Melitus Tipe 2, Kualitas Hidup, Perawatan Diri, Persepsi Penyakit

\begin{abstract}
This study aims to determine the relationship between pain perception and self-care with the quality of life of people with type 2 diabetes. This research method is a quantitative study with a cross-sectional study approach. The results showed that the majority of respondents were female, the age of the majority of respondents was 54.7 years, the majority of respondents' education was SMA-PT, the majority of DM treatment used pills / oral drugs, the majority of DM complications were neuropathy, the majority had long suffered from DM, which was an average of 7, 85 years, there is a significant relationship between pain perception and self-care, there is an important relationship between pain perception and DM quality of life, there is no critical relationship. In conclusion, there is no significant relationship between pain perception and quality of life for type 2 diabetes. There is no meaningful relationship between selfcare and quality of life for type 2 diabetes.
\end{abstract}

Keywords: Type 2 Diabetes Mellitus, Quality of Life, Self Care, Perception of Disease 


\section{PENDAHULUAN}

Diabetes Melitus (DM) merupakan kelompok penyakit metabolik dengan karakteristik hiperglikemia yang terjadi karena kelainan sekresi insulin, kerja insulin, atau keduanya (Setyawati et al., 2020). Klasifikasi DM secara umum terdiri atas DM tipe 1 atau Insulin Dependent Diabetes Melitus (IDDM) dan DM tipe 2 atau Non Insulin Dependent Diabetes Melitus (NIDDM). DM tipe 2 terjadi karena sel $\beta$ pankreas menghasilkan insulin dalam jumlah sedikit atau mengalami resistensi insulin. Jumlah penderita DM tipe 1 sebanyak 5-10\% dan DM tipe 2 sebanyak 90-95\% dari penderita DM di seluruh dunia (ADA, 2020).

DM sebagai permasalahan global terus meningkat prevalensinya dari tahun ke tahun baik di dunia maupun di Indonesia. Berdasarkan data International Diabetes Federation (IDF) prevalensi DM global pada tahun 2019 diperkirakan 9,3\% (463 juta orang), naik menjadi 10,2\% (578 juta) pada tahun 2030 dan 10,9\% (700 juta) pada tahun 2045 (IDF, 2019). Pada tahun 2015, Indonesia menempati peringkat 7 sebagai negara dengan penyandang DM terbanyak di dunia dan diperkirakan akan naik peringkat 6 pada tahun 2040 (Persatuan Diabetes Indonesia \& PERKENI, 2019).

Data terbaru dari International Diabetes Federation tahun 2017 menunjukkan bahwa Indonesia saat ini menduduki peringkat ke-6 dunia dengan jumlah penderita diabetes terbesar, yaitu sebanyak 10,3 juta jiwa (Depkes, 2018; Setyawati et al., 2020). Laporan Riskesdas tahun 2018 menyebutkan terjadi peningkatan prevalensi pada penderita DM 2,0\% pada tahun 2013 menjadi 3,4\% pada tahun 2018, dengan jumlah penderita DM di Kepulauan Riau sebesar 1,68\% (8.060 orang) dari seluruh jumlah penderita DM di Indonesia (Riskesdas, 2018).

Data angka kejadian / prevalensi DM di dunia pada tahun 2015 mencapai 415 juta jiwa dan mengalami kenaikan pada tahun 2017 yaitu 425 juta dari total populasi seluruh dunia atau sekitar 8,8\% orang dewasa yang berumur 20-79 tahun. Indonesia menempati ranking ke-6 sebagai jumlah penderita diabetes dewasa tertinggi di dunia dengan total lebih dari 10,3 juta orang setelah China (114,4 juta), India (72,9 juta), Amerika Serikat (30,2 juta), Brazil (12,5 juta) dan Meksiko (12 juta) dan angka ini diprediksi akan terus mengalami peningkatan dan mencapai 16,7 juta pada tahun 2045 (IDF, 2017).

Prevalensi DM di Indonesia semakin lama semakin meningkat, seperti diuraikan oleh Badan Litbangkes dalam Laporan Riset Kesehatan Dasar Nasional (2018), angka prevalensi diabetes di Indonesia mengalami peningkatan cukup signifikan selama 5 tahun terakhir yakni ditahun 2013 angka prevalensi diabetes pada orang dewasa mencapai 6,9\% dan di tahun 2018 mengalami peningkatan menjadi 8,5\% (Riskesdas, 2018).

Menurut Kemenkes RI tahun 2016, upaya pemerintah dalam menangani peningkatan DM yang begitu cepat dengan menerapkan sistem pelayanan penyakit tidak menular dan pelayanan penyakit kronis, tetapi sampai sekarang belum ada program khusus penanganan DM. Program pemerintah yang sudah terbentuk salah satunya adalah (1) Program Pengelolaan Penyakit Kronis (Prolanis) yang diinisiasi sejak tahun 2010 yang dapat mencegah terjadinya komplikasi pada pasien DM melalui monitoring rutin26; dan (2) Kampanye CERDIK dan PATUH pada penyakit DM.

Penyakit DM dapat menimbulkan dampak yang tidak baik terhadap kualitas hidup. Faktor gender juga berperan dalam risiko terjadinya DM. Hal ini senada dengan hasil penelitian Teli (2017) mengungkapkan ada keterikatan antara jenis kelamin dengan kualitas hidup. Pasien wanita mempunyai kualitas hidup kurang baik daripada 
pria. Secara prevalensi, wanita dan pria mempunyai peluang yang sama terkena diabetes, tetapi wanita lebih berisiko mengidap diabetes karena secara fisik wanita memiliki peluang peningkatan indeks masa tubuh yang lebih besar, sindroma siklus bulanan (premenstrual syndrome), pasca-menopouse yang membuat distribusi lemak tubuh menjadi mudah terakumulasi akibat proses hormonal tersebut sehingga wanita berisiko menderita DM tipe 2. Kondisi psikis pria pun berbeda dengan wanita dimana pria lebih bisa menerima apa yang terjadi dan bersikap positif dibandingkan wanita yang biasanya mengandalkan perasaannya saja sehingga hal tersebut akan berdampak kurang baik terhadap kualitas hidup.

Depresi tersebut biasanya terjadi akibat ketidaktahuan pasien tentang penyakitnya sehingga sangat diperlukan persepsi pasien yang baik untuk kelangsungan hidup diabetisi. Diabetes mellitus sangat bergantung terhadap persepsi sakit / cara pandang pasien terhadap penyakitnya dan juga berpengaruh terhadap cara merawat dirinya. Penderita diabetes mellitus tipe 2 akan mengalami perubahan pada dirinya. Setiap individu merespon dan mempunyai persepsi yang berbeda menghadapi perubahan tersebut.

Semakin tingginya jumlah pasien yang terkena diabetes dari tahun ke tahun diperlukan pengelolaan seumur hidup sehingga gula darah terkontrol dan mencegah komplikasi. Pengelolaan tersebut salah satunya adalah aktifitas perawatan diri, meliputi diet, medikasi, monitoring glukosa, latihan fisik dan perawatan kaki. Diabetisi perlu melakukan perawatan diri sedini mungkin, tentunya dibutuhkan kemampuan penerimaan diri pasien terhadap sakitnya. Persepsi yang salah dari pasien akan mengakibatkan pasien tidak melakukan perawatan diri dan mengambil keputusan yang salah sehingga membuat gula darah tidak stabil. Kualitas hidup diabetisi juga berperan penting dalam mengontrol gula darah dan meminimalkan munculnya komplikasi. Penelitian ini berfokus pada hubungan persepsi penyakit dan perawatan diri dengan kualitas hidup diabetes mellitus type 2 .

\section{METODE PENELITIAN}

Desain penelitian ini adalah kuantitatif dengan menggunakan rancangan pendekatan cross sectional study yaitu suatu penelitian untuk mempelajari dinamika korelasi antara faktor resiko dengan efek, dengan cara melakukan pendekatan, observasi atau pengumpulan data sekaligus pada suatu waktu.

Penelitian dilakukan dengan cara menyebar kuesioner online dikarenakan wabah pandemi covid 19 yang menjangkiti Indonesia, kuesioner yang isinya tentang identitas responden, kualitas hidup, persepsi sakit, perawatan diri diabetisi tipe 2 .

Jumlah sampel yang didapat 94 orang, awalnya terkumpul 103 responden, setelah dilakukan penyeleksian responden maka 9 orang responden tidak dimasukkan ke dalam penelitian karena tidak masuk ke dalam kriteria inklusi. Sebelum kuesioner online dikirim ke masyarakat, peneliti melakukan uji terlebih dahulu terhadap 5 orang pasien DM guna untuk melihat tingkat keakuratan bahasa yang ada di kuesioner tersebut.

Analisa data terdiri dari analisa univariat untuk mendapatkan distribusi frekuensi umur, jenis kelamin, tingkat pendidikan, pengobatan, komplikasi, lama menderita DM. Pada analisis bivariat, peneliti membagi hubungan persepsi sakit dengan kualitas hidup, hubungan perawatan diri dengan kualitas hidup, hubungan karakteristik responden dengan kualitas hidup. Pemodelan multivariat yang dilakukan pada penelitian ini dengan menggunakan uji chi square. 
HASIL PENELITIAN

Analisis Univariat

Tabel. 1

Karakteristik Responden Usia, Jenis Kelamin, Pendidikan, Pengobatan, Komplikasi dan Lama Menderita DM Tipe 2 (n-94)

\begin{tabular}{lcc}
\hline \multicolumn{1}{l}{ Karakteristik Responden } & F & $\%$ \\
\hline Usia & & \\
Dewasa akhir & 48 & 51,1 \\
Lansia akhir & 46 & 48,9 \\
\hline Jenis kelamin & 42 & \\
Laki-laki & 52 & 54,7 \\
Perempuan & & \\
\hline Pendidikan & 75 & 79,8 \\
Tinggi (SMA-PT) & 19 & 20,2 \\
Rendah (SD-SMP) & & \\
Pengobatan & 72 & 76,6 \\
Pil/ Oral & 22 & 23,4 \\
Tidak & & \\
Adamplikasi & 85 & 90,4 \\
Ada & 9 & 9,6 \\
Tidak komplikasi & & 77,7 \\
Lama sakit DM 8 tahun & 73 & 22,3 \\
\hline <6 tahun & 21 &
\end{tabular}

Berdasarkan tabel 1 menunjukan bahwa dari 94 responden, usia terbanyak adalah dewasa akhir sebanyak 51,1\%, jenis kelamin terbanyak adalah perempuan sebanyak $55,3 \%$, pendidikan terbanyak adalah pendidikan tinggi sebanyak $79,8 \%$, pengobatan paling banyak mengonsumsi pil/oral sebanyak 76,6\%, komplikasi paling banyak adalah yang mengalami komplikasi sebanyak $90,4 \%$ dan lama sakit terbanyak $>8$ tahun sebanyak $77,7 \%$.

Tabel. 2

Persepsi Sakit Responden dengan DM Tipe 2 (n-94)

\begin{tabular}{lcc}
\hline Persepsi sakit & f & $\%$ \\
\hline Baik & 45 & 47,9 \\
Kurang Baik & 49 & 51,1 \\
\hline Jumlah & 94 & 100 \\
\hline
\end{tabular}

Berdasarkan tabel 2 menunjukkan bahwa responden terbanyak memiliki persepsi kurang baik sebanyak 51,1\%.

Tabel. 3

Perawatan Diri Responden dengan

DM Tipe 2 (n-94)

\begin{tabular}{lcc}
\hline Perawatan Diri & F & $\%$ \\
\hline Baik & 45 & 47,9 \\
Kurang baik & 49 & 52,1 \\
\hline Jumlah & 94 & 100 \\
\hline
\end{tabular}


Berdasarkan tabel 3 menunjukan bahwa responden terbanyak memiliki perawatan diri kurang baik sebanyak 52,1\%.

Tabel. 4

Kualitas Hidup Responden dengan

DM Tipe 2 (n-94)

\begin{tabular}{lcc}
\hline Kualitas Hidup & F & $\%$ \\
\hline Baik & 54 & 57,4 \\
Kurang baik & 40 & 42,6 \\
\hline Jumlah & 94 & 100 \\
\hline
\end{tabular}

Berdasarkan tabel 4 menunjukan bahwa responden terbanyak memiliki kualitas hidup baik sebanyak $57,4 \%$.

\section{Analisa Bivariat}

\section{Hubungan Persepsi Sakit dengan Kualitas Hidup}

Tabel. 5

Hasil Uji Chi-Square Persepsi Sakit dengan Kualitas Hidup Diabetisi Tipe 2 (n-94)

\begin{tabular}{|c|c|c|c|c|c|c|}
\hline \multirow{3}{*}{ Persepsi Sakit } & \multicolumn{4}{|c|}{ Kualitas Hidup } & \multirow{3}{*}{$\mathrm{p}$-value } & \multirow{3}{*}{ OR } \\
\hline & \multicolumn{2}{|c|}{ Baik } & \multicolumn{2}{|c|}{ Kurang baik } & & \\
\hline & $\mathrm{F}$ & $\%$ & $\mathrm{f}$ & $\%$ & & \\
\hline Baik & 24 & 25,5 & 22 & 23,4 & & \\
\hline Kurang baik & 30 & 31,9 & 18 & 19,2 & 0,422 & 0,655 \\
\hline Total & 54 & 57,4 & 40 & 42,6 & & \\
\hline
\end{tabular}

Berdasarkan tabel 5 didapatkan nilai p-value 0,422 sehingga tidak terdapat hubungan yang signifikan antara persepsi sakit dengan kualitas hidup.

\section{Hubungan Perawatan Diri dengan Kualitas Hidup}

\section{Tabel. 6}

Hasil Uji Chi-Square Perawatan Diri dengan Kualitas Hidup Diabetes Tipe 2 (n-94)

\begin{tabular}{|c|c|c|c|c|c|c|}
\hline \multirow{3}{*}{ Perawatan Diri } & \multicolumn{4}{|c|}{ Kualitas hidup } & \multirow{3}{*}{$\mathrm{p}$-value } & \multirow{3}{*}{ OR } \\
\hline & \multicolumn{2}{|c|}{ Baik } & \multicolumn{2}{|c|}{ Kurang baik } & & \\
\hline & $\mathrm{F}$ & $\%$ & $\mathrm{f}$ & $\%$ & & \\
\hline Baik & 30 & 31,9 & 15 & 16,0 & \multirow{3}{*}{0,128} & \multirow{3}{*}{2,083} \\
\hline Kurang Baik & 24 & 25,5 & 25 & 26,6 & & \\
\hline Total & 54 & 57,4 & 40 & 42,6 & & \\
\hline
\end{tabular}

Berdasarkan tabel 6 didapatkan nilai p-value 0,128 sehingga tidak terdapat hubungan yang signifikan antara perawatan diri dengan kualitas hidup. 


\section{Analisa Multivariat Model Akhir}

Tabel. 7

Model Akhir Analisa Multivariat Usia, Pendidikan, Komplikasi, dan Perawatan Diri dengan Kualitas Hidup Diabetes (n-94)

\begin{tabular}{lccc}
\hline \multicolumn{1}{c}{ Variabel indevenden } & Exp. B & p-value & Urutan Dominan \\
\hline Usia & 0,700 & 0,428 & 4 \\
Pendidikan & 1,924 & 0,223 & 2 \\
Komplikasi & 4,743 & 0,158 & 1 \\
Perawatan Diri & 1,835 & 0,177 & 3 \\
\hline
\end{tabular}

Berdasarkan tabel 7 didapatkan hasil faktor dominan yang berhubungan dengan kualitas hidup diabetes tipe 2 adalah komplikasi dengan exp. B 4,743.

\section{PEMBAHASAN}

\section{Univariat}

\section{Karakteristik responden berdasarkan usia}

Berdasarkan hasil penelitian yang dilakukan oleh peneliti, diperoleh hasil bahwa usia rata-rata responden yang didapat dari kuesioner online adalah 51,1\% (dewasa awal- lansia awal). Menurut Riskesdas (2018) penderita diabetes mellitus yang berusia 45-54 tahun di Indonesia sebanyak 9,70 \% dan meningkat menjadi 11,20\% pada usia $>55$ tahun. Penelitian ini sejalan dengan penelitian Panelewen et al., (2017) yang menyatakan bahwa mayoritas responden berusia 51-55 tahun yaitu sebanyak $14(36,8 \%)$ responden. Penelitian yang dilakukan Rini et al., (2019) menunjukkan bahwa mayoritas responden dengan lama menderita DM berusia elderly yaitu sebanyak 18 (60\%) responden.

Usia tua yang dapat mempengaruhi diabetes karena fungsi tubuh secara fisiologi menurun dan terjadi penurunan sekresi atau resistensi insulin sehingga kemampuan fungsi tubuh terhadap pengendalian glukosa darah yang tinggi kurang optimal dan jenis kelamin mempengaruhi kadar glukosa darah dimana laki-laki beresiko terkena diabetes tipe 2 dibandingkan dengan perempuan (Latiifah \& Rosyid, 2020; Yosmar et al., 2018).

Faktor usia dapat mempengaruhi penurunan pada sistem tubuh, tidak terkecuali sistem endokrin. Penambahan usia menyebabkan kondisi resistensi pada insulin yang mengakibatkan tidak stabilnya kadar gula darah sehingga banyaknya kejadian DM salah satunya disebabkan oleh faktor penambahan usia yang secara degeneratif menyebabkan penurunan fungsi tubuh (Isnaini \& Ratnasari, 2018; Mutia \& Lubis, 2021).

\section{Karakteristik Responden Berdasarkan Jenis Kelamin}

Berdasarkan hasil penelitian yang dilakukan oleh peneliti, diperoleh hasil bahwa mayoritas responden yang didapat dari kuesioner online adalah berjenis kelamin perempuan yaitu sebanyak 52 orang $(55,3 \%)$. Penelitian ini sejalan dengan penelitian Komariah \& Rahayu (2020) yang menunjukkan bahwa responden sebagian besar pasien diabetes mellitus tipe 2 berusia 46-65 tahun sebanyak 93\% (69,4\%), berjenis kelamin perempuan sebanyak $81 \%(60,4 \%)$.

Sejalan dengan penelitian yang dilakukan Usman et al., (2020) yang menunjukkan bahwa dari 63 responden yang menderita diabetes mayoritas memiliki jenis kelamin perempuan sebanyak $69,8 \%$. Hal ini disebabkan karena pola makananya yang tidak 
sehat seperti sering mengkonsumsi makanan yang berlemak dan mengandung glukosa yang tinggi.

\section{Karakteristik Responden Berdasarkan Pendidikan}

Berdasarkan hasil penelitian yang dilakukan oleh peneliti, diperoleh hasil tingkat pendidikan bahwa mayoritas responden adalah berpendidikan tinggi (sekolah menengah atas sampai perguruan tinggi) yaitu sebanyak 75 orang $(79,8 \%)$. Tingkat pendidikan dapat meningkatkan pengetahuan seseorang tentang kesehatan. Semakin banyak informasi yang masuk semakin banyak pula pengetahuan yang didapat tentang kesehatan. Pendidikan merupakan faktor penting dalam memahami penyakit, perawatan diri, pengelolaan penyakit, mengatasi gejala yang muncul dengan penanganan secara tepat serta mencegah terjadinya komplikasi (Utami \& Masnina, 2019).

Hasil penelitian yang dilakukan Mutia \& Lubis (2021) menunjukkan bahwa pasien dengan pendidikan dasar lebih besar proporsinya dibandingkan pasien dengan pendidikan lanjutan. Namun, hal ini bukan berarti bahwa pasien dengan pendidikan dasar lebih beresiko untuk menderita ulkus. Hal tersebut hanya menunjukkan bahwa penderita yang berobat ke RSU Haji Medan lebih banyak yang berpendidikan dasar.

\section{Karakteristik Responden Berdasarkan Lama Menderita DM}

Hasil penelitian yang telah dilakukan oleh peneliti didapatkan lama menderita DM responden rata-rata menderita $\geq 8$ tahun sebanyak 73 orang $(77,7 \%)$. Hal ini sejalan dengan penelitian Setiyorini \& Wulandari (2017) yang menyatakan bahwa sebagian besar responden diabetes mellitus memiliki riwayat lama menderita DM $>5$ tahun. Hasil penelitian Suri et al., (2020) menunjukkan bahwa sebagian besar responden memiliki riwayat lama menderita $\mathrm{DM}>10$ tahun sebanyak $19(47,5 \%)$ responden.

\section{Karakteristik Responden Berdasarkan Komplikasi DM}

Komplikasi pada DM tipe 2 dapat dilihat dari hasil penelitian yaitu mayoritas responden yang mengalami komplikasi sebanyak 85 orang $(90,4 \%)$. Hal ini sejalan dengan penelitian Hutapea et al., (2016) yaitu kejadian neuropati diabetik terbanyak pada usia 45-65 tahun. Banyaknya penderita neuropati pada rentang usia 45-65 tahun ini disebabkan karena pada usia tersebut terjadi kerusakan jaringan yang disebabkan oleh radikal bebas seperti peningkatan kadar lipid peroksida dan perubahan aktivitas enzim. Penelitian yang dilakukan Prasetiyo \& Asnindari (2017) menunjukkan bahwa distribusi frekuensi yang memiliki komplikasi pasien diabetes mellitus sebanyak $17(42,5 \%)$ responden.

\section{Bivariat}

\section{Hubungan antara Persepsi Sakit dengan Kualitas Hidup DM Tipe 2}

Analisis statistik didapatkan nilai p-value 0,422 yang artinya menunjukkan tidak terdapat hubungan yang signifikan antara persepsi sakit dengan kualitas hidup. Didapatkan juga nilai OR 0,655 yang artinya responden yang memiliki persepsi sakit positif akan berpeluang 1,45 memiliki kualitas hidup.

Hasil penelitian ini bertentangan penelitian yang dilakukan Rafi'ah \& Perwitasari (2017) yang menyatakan bahwa ada hubungan bermakna antara persepsi tentang penyakit dengan kualitas hidup pada pasien DM tipe 2 dengan komplikasi. Sejalan dengan penelitian Santoso et al., (2017) yang menunjukkan bahwa tingkat pendidikan 
dan persepsi tentang penyakit yang dimiliki pasien berpengaruh terhadap kualitas hidupnya.

\section{Hubungan antara Perawatan Diri dengan Kualitas Hidup DM Tipe 2}

Berdasarkan analisa statistik didapatkan nilai $p$-value 0,128, hal tersebut menunjukkan tidak terdapat hubungan yang signifikan antara perawatan diri dengan kualitas hidup. Selain itu didapatkan nilai OR 2,083 hal tersebut bermaksud bahwa responden yang memiliki perawatan diri baik akan berpeluang 2,083 kali memiliki kualitas hidup baik.

Berbeda dari hasil penelitan sumber lainnya yang dilakukan oleh Chaidir et al., (2017) di wilayah kerja Puskesmas Tigo Baleh yang memiliki nilai yang signifikan didapatkan hubungan yang berbanding lurus antara self care dengan kualitas hidup DM tipe 2. Hasil penelitian Rahman et al., (2017) menunjukkan bahwa variabel efikasi diri, kepatuhan, depresi dan tingkat pendidikan menentukan kualitas hidup pasien DM.

\section{Hubungan Karakteristik dengan Kualitas Hidup DM Tipe 2}

Berdasarkan hasil uji statistik bivariat antara karakteristik responden dengan kualitas hidup menunjukkan bahwa seluruh karakteristik responden baik usia, jenis kelamin, pendidikan, lama menderita DM, obat dan komplikasi tidak berhubungan secara signifikan dengan kualitas hidup.

\section{SIMPULAN}

Tidak terdapat hubungan yang signifikan antara persepsi sakit dengan kualitas hidup DM tipe 2. Tidak terdapat hubungan yang signifikan antara perawatan diri dengan kualitas hidup DM tipe 2.

\section{DAFTAR PUSTAKA}

ADA. (2020). Classification and Diagnosis of Diabetes: Standards of Medical Care in Diabetes-2020. In Diabetes care (Vol. 43, pp. S14-S31). https://doi.org/10.2337/dc20-S002

Chaidir, R., Wahyuni, A. S., \& Furkhani, D. W. (2017). Hubungan Self Care dengan Kualitas Hidup Pasien Diabetes Melitus. Jurnal Endurance, 2(2), 132. https://doi.org/10.22216/jen.v2i2.1357

Depkes, R. I. (2018). Data dan Informasi Profil Kesehatan Indonesia.

Hutapea, G., Ariosta, A., \& Hardian, H. (2016). Perbandingan Kadar Glukosa Darah Setelah Mengonsumsi Coca-Cola Reguler dan Coca-Cola Zero pada Populasi Non-Diabetes. Jurnal Kedokteran Diponegoro, 5(4), 892-902

IDF. (2017). IDF Diabetes Atlas Eighth edition 2017. In International Diabetes Federation. IDF Diabetes Atlas, 8th edn. Brussels, Belgium: International Diabetes Federation, 2017. http://www.diabetesatlas.org. https://doi.org/http://dx.doi. org/10.1016/S0140-6736(16)31679-8

IDF. (2019). IDF Diabetes Atlas 9th edition 2019. In International Diabetes Federation Diabetes Atlas, Ninth Edition. https://www.diabetesatlas.org/en/

Isnaini, N., \& Ratnasari, R. (2018). Faktor Risiko Mempengaruhi Kejadian Diabetes Tipe Dua. Jurnal Keperawatan Dan Kebidanan Aisyah, 14(1), 59-68 
Komariah, K., \& Rahayu, S. (2020). Dengan Kadar Gula Darah Puasa pada Pasien Diabetes Melitus Tipe 2 di Klinik Pratama Rawat Jalan. Jurnal Kesehatan Kusuma Husada, 11(1), 41-50. http://jurnal.ukh.ac.id/index.php/JK/article/view/412/320

Latiifah, I. R. N., \& Rosyid, F. N. (2020). Hubungan antara Karakteristik Responden dengan Kadar Glukosa Darah Puasa pada Penderita Diabetes Melitus Tipe 2 di Puskesmas Purwosari Surakarta [Universitas Muhammadiyah Surakarta]. http://eprints.ums.ac.id/83969/1/Naskah Publikasi Itsnaani.pdf

Mutia, A., \& Lubis, R. (2021). Faktor-Faktor yang Berhubungan dengan Kejadian Komplikasi Sirkulasi Perifer Pasien DM Tipe 2 di Rs Haji Medan Tahun 20192020 [Universitas Sumatera Utara]. http://repositori.usu.ac.id/bitstream/handle/123456789/30410/161000092.pdf

Panelewen, R., Rumbayan, J. M., \& Satiawati, L. (2017). Hubungan Usia Penyandang Diabetes Melitus Tipe 2 dan Disfungsi Ereksi. Jurnal E-Biomedik, 5(2). https://doi.org/10.35790/ebm.5.2.2017.17513

Persatuan Diabetes Indonesia, \& PERKENI. (2019). Pedoman Pengolaan dan Pencegahan Prediabetes di Indonesia 2019. In Journal of Chemical Information and Modeling (Vol. 53, Issue 9)

Prasetiyo, H., \& Asnindari, L. N. (2017). Analisis Hubungan Faktor Lama Menderita dan Komplikasi Penyakit dengan Kualitas Hidup Pasien Diabetes Melitus di Rumah Sakit PKU Muhammadiyah Bantul [Universitas 'Aisyiyah Yogyakarta]. http://digilib.unisayogya.ac.id/2537/1/Naskah Publikasi.pdf

Rafi'ah, N., \& Perwitasari, D. A. (2017). Hubungan Persepsi tentang Penyakit dengan Kualitas Hidup pada Pasien Diabetes Melitus Tipe 2 dengan Komplikasi di RSUD Abdul Wahab Sjahranie Samarinda. Media Farmasi: Jurnal Ilmu Farmasi, 14(1), 103-118. https://doi.org/10.12928/mf.v14i1.9830

Rahman, H. F., Yulia, Y., \& Sukmarini, L. (2017). Efikasi Diri, Kepatuhan, dan Kualitas Hidup Pasien Diabetes Melitus Tipe 2. E-Jurnal Pustaka Kesehatan, 5(1), 108-113. https://jurnal.unej.ac.id/index.php/JPK/article/view/4059/3172

Rini, P. S., Apriany, A., \& Romadoni, S. (2019). Hubungan antara Usia dan Lama Menderita DM dengan Kejadian Disfungsi Ereksi (DE) pada Pasien Diabetes Melitus. Babul Ilmi: Jurnal Ilmiah Multi Science Kesehatan, 11(1), 196-205. https://doi.org/https://doi.org/10.36729/bi.v11i1.271

Riskesdas. (2018). Hasil Utama Riset Kesehatan Dasar. Kementrian Kesehatan Republik Indonesia, 1-100. https://doi.org/https://doi.org/10.1088/17518113/44/8/085201

Santoso, S. B., Perwitasari, D. A., Faridah, I. N., \& Kaptein, A. (2017). Hubungan Kualitas Hidup dan Persepsi Pasien tentang Penyakit Diabetes Mellitus Tipe 2 dengan Komplikasi. Pharmaciana, $\quad 7(1), \quad 33-40$. https://doi.org/10.12928/pharmaciana.v7i1.4699

Setiyorini, E., \& Wulandari, N. A. (2017). Hubungan Status Nutrisi dengan Kualitas Hidup pada Lansia Penderita Diabetes Mellitus Tipe 2 yang Berobat di Poli Penyakit dalam RSD Mardi Waluyo Blitar. Jurnal Ners Dan Kebidanan, 4(2), 125-133

Setyawati, A. D., Ngo, T. H. L., Padila, P., \& Andri, J. (2020). Obesity and Heredity for Diabetes Mellitus among Elderly. JOSING: Journal of Nursing and Health, 1(1), 26-31. https://doi.org/https://doi.org/https://doi.org/10.31539/josing.v1i1.1149 
Suri, A. A. L., Mutiara, H., Sari, M. I., Muhartono, M., \& Falamy, R. (2020). Hubungan antara Lama Menderita Diabetes Melitus Tipe 2 dengan Kejadian Peripheral Arterial Disease (PAD) pada Pasien Diabetes Melitus Tipe 2 di Puskesma Kedaton Kota Bandar Lampung. Medula, 9(4), 379-384. http://repository.lppm.unila.ac.id/22104/1/DM dgn PAD.Adinda,HM.pdf

Teli, M. (2017). Kualitas Hidup Pasien Diabetes Melitus Tipe 2 di Puskesmas Se Kota Kupang. Jurnal Info Keperawan, 15(1), 119-134. https://doi.org/https://orcid.org/0000-0002-0278-7981

Usman, J., Rahman, D., Rosdiana, R., \& Sulaiman, N. (2020). Faktor yang Berhubungan dengan Kejadian Diabetes Mellitus pada Pasien di RSUD Haji Makassar. Jurnal Komunitas Kesehatan Masyarakat, 2(1), 16-22. 759-Article Text-2387-1-10-20200806.pdf

Utami, F. R., \& Masnina, R. (2019). Gambaran Kualitas Hidup Penderita Diabetes Melitus di Puskesmas Air Putih Samarinda. https://dspace.umkt.ac.id//handle/463.2017/1656

Yosmar, R., Almasdy, D., \& Rahma, F. (2018). Survei Risiko Penyakit Diabetes Melitus terhadap Masyarakat Kota Padang (Risk Survey of Diabetes Melitus Against Padang People). Jurnal Sains Farmasi Dan Klinis, 5(2442-5435), 134141. http://jsfk.ffarmasi.unand.ac.id 